\title{
marife
}

dini araştırmalar dergisi

Turkish Journal of Religious Studies

cilt / volume: 19 • sayı / issue: 1 • yaz / summer 2019

\section{Hanefî Usul Düşüncesinde Emrin Veya Me'mûr Bihin Kaydı Olarak Vakitler (Vakit Teorisinin Gelişimi Üzerine Bir İnceleme)}

\section{Mehmet Ümütli}

Dr. Öğr. Üyesi, Pamukkale Üniversitesi İlahiyat Fakültesi

Temel İslam Bilimleri Bölümü İslam Hukuku Anabilim Dalı

mehmetumutli66@gmail.com | https://orcid.org/0000-0002-7195-7200

Geliş Tarihi / Received: 15.04.2019 • Yayına Kabul Tarihi / Accepted: 26.06 .2019

$\ddot{O} z$

Vakit, insan hayatında yadsınamaz önemi haiz olan kavramlar arasında yer almaktadır. İslam dini de kimi ibadet ve sorumlulukları vakitle ilișkilendirmiștir. Konunun bu öneminden hareketle İslam hukukçuları da özelde ibadetlerin genelde ise tüm sorumlulukların vakitle irtibat ve ilişsi yönü hususunda farkl yaklaşımlar ortaya koymuşlardır. Hanefi fikıh usulü geleneği incelendiğinde Şâri' in mükelleften yapmasını istediği șeyin veya mükellefe sorumluluk yükleyen hitabının, belirli bir vakitle sınırlandırılıp sınırlandırılmaması yönüyle bazı taksimler yapıldı̆ğ görülmektedir. Konuyla ilgili olarak genelde "geniş vakit", "dar vakit" ve "müşsil vakit" şeklinde üçlü bir sınıflandırma söz konusudur. Bununla birlikte Hanefi usul âlimleri kendi usul anlayışlarının bir yansıması olarak farklı teoriler ortaya koymuşlar ve konunun anlaşılması için bazı katkılar yapmışlardır. Bu sayede mükellefin sorumluluk alanına giren hususların vakitle irtibat yönünün teorik arka planının sağlam bir şekilde kurgulanmasının amaçlandığı ifade edilebilir. Bu makalede Hanefì usulcülerinin emrin veya me'mûr bihin bir kaydı olması itibariyle vakit çeşitleri hakkındaki yaklaşımlarını ve bu yönüyle vakit teorisinin gelișimine yapmıs oldukları katkıları incelemeye çalışacağız.

Anahtar Kelimeler: Vakit, İbadetler, Geniş Vakit, Dar Vakit, Müsskil Vakit.

The Times as an Additional Thing of the Commandment or Commanded Thing in the Hanafi's Tought of Usul al-Fiqh (A Study on the Development of Time Theory)

Time is one of the concepts that have undeniable importance in human life. Islam has associated some worship and responsibilities with time. Based on the importance of this issue, Islamic jurists have shown different approaches especially to worship and in general about the connection and relationship aspect of all responsibilities. When the tradition of Hanafi's usul al-fiqh is examined, it can be seen that some partitions have been done in order to determine whether that Shari wanted to do from responsible (mukallaf) or his speech that imposed responsibility for the responsible was limited to a certain time. In general, there is a triple classification in the form of a "wide time", "narrow time" and "equivocal time". However, Hanafi scholars have presented different theories as a reflection of their understanding of usul al-fiqh and made some contributions to understand the subject. In this way, it can be stated that it is aimed to explain the theoretical background of the point of contact of the things that fall under the responsibility of the responsible (mukallaf). In this article, we will try to examine the approaches of Hanafi scholars of usul al-figh about the types of time as a feature of the commandment or commanded thing and their contribution to the development of time theory.

Keywords: Time, Worships, Wide Time, Narrow Time, Equivocal Time. 


\section{Atıf / Cite as}

Ümütli, Mehmet. "Hanefî Usul Düşüncesinde Emrin Veya Me'mûr Bihin Kaydı Olarak Vakitler (Vakit Teorisinin Gelişimi Üzerine Bir İnceleme)”. Marife 19/1 (2019): 123-139. https://doi.org/10.33420/marife.554090.

\section{Giriş}

İslam dini insan hayatına dair birtakım düzenlemeler getirmiştir. İnsan hayatında merkezi bir konumda yer alan ibadetler ve diğer bazı sorumluluklar düzenlenirken vakitle ilişkilendirildiği görülmektedir. ${ }^{1}$ Fürû-i fıkıh kaynakları incelendiğinde özellikle ibadetlerin vakitle ilgili özelliklerine ve ilgili tartışmalara yer verildiği görülmektedir. Bununla birlikte konunun teorik bir yönü de bulunmaktadır. Bu noktadan hareket eden fikıh usulü âlimleri, Şârî̀in teklif ifade eden hitâbı ile "me'mûr bih" yani "emredilen" vasfını kazanan hususun vakitle ilişki ve irtibat yönünü incelemişler ve farklı tasnif ve taksimler yaparak konuya katkı sağlamışlardır. Hanefî fikı usulü geleneği incelendiğinde konunun erken dönemlerden itibaren ele alındığı söylenebilir. Bununla birlikte kimi usulcülerin, konuya dair yaklaşımları ve eleştirileriyle, teorinin geliştirilmesine katkı sağladıkları görülmektedir. Bu makalede Hanefî usul geleneği içerisinde söz konusu hususun gelişiminin incelenmesi, Hanefî usul âlimlerinin konuya dair yaklaşımlarının tespit ve tahlilinin yapılması hedeflenmektedir.

\section{Mutlak ve Mukayyed Emir}

Fıkıh usulünde mutlak emir, "umuma, hususa, tekrara veya bir kereliğe delalet eden herhangi bir karine taşımayan emir" olarak ifade edilmektedir. Mukayyed emir ise söz konusu karinelerden herhangi birini taşıyan emirdir. ${ }^{2}$ Emrin mutlak olup olmamasında temel ayrım bu olmakla birlikte, herhangi bir vakitle kayıtlı olup olmaması yönüyle de emrin mutlak ve mukayyed olarak kısımlandırılması da söz konusudur. Buna göre mutlak emir; yapılması istenilen işin, geciktirilerek yapılması halinde kazâ veya gayr-i meșrû olacak şekilde herhangi bir vakitle kayıtlanmadığı emre karşılık gelmektedir. Mukayyed emir ise yapılması istenen şeyin belirli bir vakit içinde yapılmasını öngören emirdir. ${ }^{3}$ Vakitle kayıtlanmış olan emirle, mükelleften yapılması istenen șeyin (me'mûr bih), emrin öngörmüș olduğu vakit içerisinde yapılması durumu söz konusudur. ${ }^{4}$ Bu yönüyle vakit açısından mukayyed olan emirle yapılması talep edilen șeyin, belirlenen vakitten sonra yapılması durumunda

1 Yahyâ Maabdeh, “el-Ehâdîsü'l-vâride fî tahdîdi bed'i duhûli vakti'l-mağrib dirâseten fikhiyyeten nakdiyyeten fî dav'i ilmi'l-felek”, İslam Hukuku Araștırmaları Dergisi 31 (Nisan 2018): 473.

2 Cessâs, Ebû Bekir Ahmed b. Ali er-Râzî, el-Füsûl fi'l-usûl, thk. Uceyl Câsim en-Neșemî (Kuveyt: Vizâretü'l-evkâf ve'ş-șuûni'l-İslâmiyye, 1994), 2: 133, 134, 237; Abdülazîz el-Buhârî, Alâüddîn b. Ahmed b. Muhammed, Keșfu'l-esrâr an Usûl-i Fahri'l-İslâm el-Pezdevî (İstanbul: Șirket-i Sahâfe-i Osmâniye, 1308/1890), 1: 123; Seydișehrî, Mahmud Esad, Teshîl-u Usûl-i Fıkıh (İstanbul: Yasin Yayınları, 2002), 34

3 Hanbelîzâde, Muhammed Şâkir (1876-1958), Usûlü'l-fikhi'l-İslâmî (Beyrût: Dârü'l-Beşâir, 2004 ), 71.

4 Cessâs, el-Füsûl fi'l-usûl, 2: 107. 
kazâ veya gayr-i meşrû olma gibi hususlar söz konusu olmaktadır. ${ }^{5}$ Buna karşın vakit açısından mutlak olan yani herhangi bir vakitle sınırlandırılmamış emirde, söz konusu emre muhatap olan mükellef, kendisine emredilen şeyi dilediği zaman yerine getirebilme imkânına sahip olmaktadır. ${ }^{6} \mathrm{Bu}$ itibarla bu tür mukayyed olan emrin veya me'mûr bihin vakit açısından sınıflandırılmasının, mükellefin sorumluluk alanının doğru bir şekilde tespit edilmesi açısından önemli olduğu söylenebilir.

\section{Vakitle Kayıtlanmıș Emirlerde Vaktin Çeșitleri}

Hanefî usul geleneğinde "vakitle kayıtlanmış olan emirler" konusunda, gerek sınıflandırma gerekse içerik açısından birbirinden farklı yaklaşımların ortaya konduğu söylenebilir. Hanefî usulcülerinden Cessâs (ö. 370/981) ve Serahsî (ö. 483/1090) konuyu "muvakkat emir" başlığı altında ele almışlardır. ${ }^{7}$ Bu başlık altında Cessâs, yalnızca namaz vaktine değinmiş, vaktin diğer türlerine temas etmediği gibi herhangi bir taksime de yer vermemiştir. ${ }^{8}$ Serahsî ise emrin bir kaydı olması yönüyle vakti üç kısma ayırmış ve bu sınıflandırma üzerinden ilgili hükümlere değinmiştir. ${ }^{9}$ Debûsî (ö. 430/1039) ve Pezdevî’nin (ö. 482/1089) ise konuyu "muvakkat ibadetler" başlığı altında inceledikleri görülmektedir. ${ }^{10}$ Debûsî, bu başlık altında vakitleri üç kısma ayırırken Pezdevî farklı bir yaklaşım benimsemiş ve vakitleri dört kısma ayırmak suretiyle incelemiştir. ${ }^{11}$ Sonraki dönem Hanefî usulcülerinden Ebü’lBerekât en-Nesefî (ö. 710/1310), fıkıh usulüne dair kaleme aldığı Menârü'l-Envâr adlı çalışmasında konuyu "Vakitle kayıtlı olan emir" başlığı altında incelerken ${ }^{12}$ aynı metin üzerine yazmış olduğu şerhinde konuya dair açmış olduğu bölüme "Vaktin hükümleri açısından me'mûr bihin kısımları" başlığını kullanmıştır. ${ }^{13}$ Kanaatimizce Nesefî, bu tavriyla kendisinden önceki Hanefî usul âlimlerinin konuyu isimlendirmeleri hususunda ortaya koydukları farklı yaklaşımları birleştirici bir tutum sergilemiş ve söz konusu ihtilafin hakikî olmayıp lafzî bir ihtilaf olduğuna işarette bulunmuştur. Sonraki dönem Hanefî usul âlimlerinden Molla Fenârî̀nin (ö. 834/1431) ise konuyla ilgili farklı bir yaklaşım benimsediği görülmektedir. Molla Fenârî, fıkıh

5 Örneğin, bir kimse belirli bir mevsimde lazım olan bir şeyi satın alması için bir başkasına vekâlet verse, bu emir o mevsimle sınırlanmış olur. Mevsim bitince o șey satın alınsa, satın alma işlemi müvekkil hakkında geçerli olmaz. (Bk. Mecelle, md. 1484)

6 Örneğin zekât emri bu tür bir emirdir. Zira herhangi bir vakitle kayıtlanmamıștır. Dolayısıyla emredilen kişi ne zaman zekât verirse versin, bu fiili kazâ değil edâdır. Ayrıca zekât vermenin geciktirilmesi durumunda da herhangi bir gayr-i meşrûluk söz konusu olmamaktadır. (Bk. Seyyid Bey, Usûl-i Flkıh Dersleri (İstanbul: y.y., 1913), 62, 63).

7 Cessâs, el-Füsûl fi'l-usûl, 2: 123; Serahsî, Ebû Bekir Muhammed b. Ahmed b. Ebî Sehl, el-Usûl, thk. Ebû'lVefâ el-Afğânî (Beyrût: Dâru'l-Fikr, 2005), 1: 30.

8 Cessâs, el-Füsûl fi'l-usûl, 2: 123-132.

9 Serahsî, el-Usûl, 1: 30-44.

10 Debûsî, Ebû Zeyd Abdullahb. Muhammed b. Ömer b. Îsâ, Takvîmu'l-edille fi usûli'l-fikh, thk. Halil Muhyiddin Meys (Beyrût: Dârü'l-kütübi'l-ilmiyye, 1421/2001), 67; Pezdevî, Ebü'l-Hasen Ebü'l-Usr Fahrü'l-İslâm Alî b. Muhammed b. el-Hüseyn b. Abdilkerîm, el-Usûl (İstanbul: Şirket-i Sahâfe-i Osmâniye, 1308/1890), 1: 213.

11 Bk. Debûsî, Takvîmu'l-edille, s. 67-76; Pezdevî, el-Usûl, 1: 213-256.

12 Bk. Nesefî, Ebü'l-Berekât Hâfıüddîn Abdullah b. Ahmed b. Mahmûd, Menârü'l-envâr (Dimaşk: Dârü’lFarfûr, 2001), 50.

13 Bk. Nesefî, Ebü'l-Berekât Hâfızüddîn Abdullah b. Ahmed b. Mahmûd, Keş̧fu'l-esrâr şerhu'l-musannif ale'l-Menâr (İstanbul: İhsan Kitabevi, 1986), 1: 80. 
usulü alanında yazmış olduğu Füsûlü'l-bedâyı̂‘ adlı eserinde, kendisinden önceki Hanefî alimlerinden farklı olarak konuyu "emir", "me'mûr bih" bağlamında değil, hüküm teorisi kapsamında ve edâ konusu özelinde incelemiştir. Edâyı belirli bir vakitle kayıtlı olup olmaması açısından, mutlak ve mukayyed şeklinde iki kısma ayıran Molla Fenârî, zamanla kayıtlı olan mukayyed edâyı, vakitleri açısından altı kısma taksim ederek ele almıştır. ${ }^{14}$ Molla Fenârî tarafından ortaya konan bu taksimin, sonraki Hanefî usulcülerinden Molla Hüsrev (ö. 885/1480) tarafından büyük oranda benimsendiği görülmektedir. Bununla birlikte Molla Hüsrev, söz konusu taksimi edânın vakit açısından kısımları kapsamında değil emir konusu içerisinde ve "vakitle kayıtlı emir" başlığı altında incelemiştir. ${ }^{15}$

\subsection{Zarf, Şart ve (Vücûb İçin) Sebep Olan Vakit}

Vaktin bu kısımı için Debûsî "müvessa" ifadesini kullanırken Pezdevî, Serahsî ve Molla Hüsrev'in "zarf” ifadesini kullandıkları görülmektedir. ${ }^{16}$ Molla Fenârî ise hem "müvessa" hemde "zarf" ifadelerini kullanmıștır. ${ }^{17}$ Farz namazların vakitleri bu tür vakitlerdendir. Debûsî’nin ifadesiyle bu tür vakitler, emredilen şeyin yerine getirilmesi için yeterli olan ve aynı cinsten başka ibadetlerin yapılmasına da imkân veren geniş vakitlerdir. ${ }^{18}$ Namazın vakti, namazın zarfı olmaktadır, yani hem o vakitte kılınması gereken farz namazın edâsına yetmekte hem de başka namazların kılınabilmesine imkân verecek ölçüde artmaktadır. ${ }^{19}$ Bu tür vakit aynı zamanda edâ edilecek sorumluluğun şartı ve vücûb sebebi olmaktadır. Debûsî, namaz örneğinden hareketle vaktin, namazın şartı olduğunu ifade ederken vücûbunun sebebi olmasına değinmemektedir. ${ }^{20}$ Buna karşın Pezdevînnin, namaz vaktinin zarf, şart ve sebep olma yönünü net bir şekilde ifade ettiği görülmektedir. Pezdevî̀nin ifadesiyle namaz vakti, namazın edâsından fazla olduğu için namazın zarfı, namazın edâ edilmesi vaktin çıkmasıyla ortadan kalktığı için de edâsının şartıdır. ${ }^{21}$ Ayrıca namaz vakti girmeden namaz kılınmasının mümkün olmaması açısından vakit, namazın vücûbunun sebebi olmaktadır. ${ }^{22}$ Molla Hüsrev'in de bu konuda benzer izahlarda bulunarak Pezdevî'nin yaklaşımını sürdürdügü görülmektedir. ${ }^{23}$

Vaktin bu türünde vaktin tamamını, edâ edilecek olan șeyin (müeddânın) vücûbu için sebep saymak mümkün olmamaktadır. Zira bir şeyin başka bir şeye hem zarf hem de sebep olması birbirine aykırı iki durumdur. Vaktin tamamının sebep

\footnotetext{
14 Bk. Molla Fenârî, Şemseddîn Muhammed b. Hamza b. Muhammed, Füsûlü'l-bedâyî́ fî usûli'ş-şerâi', thk. Muhammed Hasen Muhammed Hasen İsmail (Beyrût: Dârü'l-Kütübi'l-İlmiyye, 2006), 1: 218-230.

15 Molla Hüsrev, Mehmed, Mir'âtü'l-usûl (İstanbul: Salah Bilici Kitapevi, ts.), 70.

16 Bk. Debûsî, Takvîmu'l-edille, 67; Pezdevî, el-Usûl, 1: 213; Serahsî, el-Usûl, 1: 30; Molla Hüsrev, Mir'âtü'lusûl, 70.

17 Molla Fenârî, Füsûlü'l-bedâyî',1: 218.

18 Debûsî, Takvîmu'l-edille, 67.

19 Pezdevî, el-Usûl, 1: 213; Molla Fenârî, Füsûlü'l-bedâyî',1: 218; Molla Hüsrev, Mir'âtü'l-usûl, 70.

20 Debûsî, Takvîmu'l-edille, 70

21 Pezdevî, el-Usûl, 1: 213.

22 Pezdevî, el-Usûl, 1: 213, 214.

${ }^{23}$ Molla Hüsrev, Mir'âtü'l-usûl, 70, 71
} 
sayılması durumunda edânın, vaktinden sonraya bırakılması (tehiri) veya vaktinden öne alınması (takdimi) söz konusu olmaktadır. ${ }^{24}$ Örneğin vaktin tamamı geçmeden vaktin herhangi bir kısmında kılınan namaz, sebebi tam olarak meydana gelmeden edâ edilmiş olacağından müsebbeb olan namaz, sebebi olan vaktin önüne geçmiş olacaktır. Aynı şekilde namaz, vaktin tamamlanmasından sonra kılınacak olsa, namazın edâsı vaktin çıkmasından sonraya bırakılmış olur ki bu durumda namaz, vaktinde kılınmamış yani edâ eylemi vakit içerisinde gerçekleşmemiş olacaktır. ${ }^{25}$

Yukarıdaki açıklamalardan da anlaşıldığı gibi vaktin bu türünde vaktin tamamının müeddâya sebep yapılması uygun değildir. Dolayısıyla vaktin bir cüz'ünün (kısmının) sebep kılınması durumu zorunlu olarak sabit olmaktadır. Hanefî usulcülerinden Debûsî, konuyla ilgili herhangi bir görüş ortaya koymazken Pezdevî, vaktin sebep olmaya uygun olan kısmının, edâdan önceki vakit olduğunu net bir şekilde belirtmekte ve bu durumda vaktin en küçük cüz'üyle yetinmenin gerekliliğini ifade etmektedir. ${ }^{26}$ Sebep olma hususunda öncelikli kısım, vaktin ilk cüz'üdür. ${ }^{27}$ Sebep, vaktin ilk cüz'ü olduktan sonra eğer o ilk cüz'ü şurû' yani emredilen şeyi yerine getirmeye başlama takip ederse, sebep olma vasfı vaktin o cüz'üne yerleşir ve o kısım, söz konusu ibadetin sebebi olmuş olur. ${ }^{28}$ Eğer ilk cüz'ü şurû' takip etmezse bu sebebiyyet, sonrası iftitah tekbirini içine alacak son cüz'e kadar sırayla intikal etmekte ve vaktin hangi kısmında ibadete başlama eylemi gerçekleştirilirse orası ibadetin sebebi olmaktadır. ${ }^{29}$

Abdulazîz el-Buhârî̀nin ifadesiyle Ebû Hanîfe (ö. 150/767), Ebû Yûsuf (ö. 182/798), Muhammed eş-Şeybânî (ö. 189/805), Şâfiî (ö. 204/820) ve ashabına göre namaz vaktinden herhangi bir cüz'ün bulunması durumunda gayr-i müslim birisi müslüman olsa, o vaktin farzıyla sorumlu olur yani o kişinin namazı edâ etmesi, edâ edememişse kazâ etmesi gerekir. Zira namaza ehil olduğu bir halde iken namazın sebebi olan vakit bulunmaktadır. ${ }^{30}$ Bununla birlikte Şafî̂lerden farklı olarak Hanefîlere göre mükellef, namaz vaktinin sonunda ölmüş olsa o vaktin namazıyla sorumlu değildir. ${ }^{31}$ Zira Hanefî mezhebinde yaygın olan bakış açısına göre vaktin son kısmında ehliyetin ortaya çıkması ve aynı şekilde ehliyetin ortadan kalkması itibara alınmaktadır. Örneğin iftitah tekbirine yetecek kadar bir vakitte namaza ehil olan kişi, örneğin hayızdan kesilen kadın veya bulûğa eren çocuk, bu namazla sorumlu olup kazâ etmesi gerekmektedir. ${ }^{32}$ Çünkü vaktin herhangi bir cüz'ü namazın sebebidir ve mükellef de sebep olan o vakte ulaşmış durumdadır. Bununla birlikte mükellef

\footnotetext{
24 Pezdevî, el-Usûl, 1: 213; Molla Fenârî, Füsûlü'l-bedâŷ̂',1: 218; Molla Hüsrev, Mir'âtü'l-usûl, 70.

25 Pezdevî, el-Usûl, 1: 214; Apaydın, Yunus, İslam Hukuk Usulü (Kayseri: Kimlik Yayınları, 2016), $139,140$.

26 Pezdevî, el-Usûl, 1: 214.

27 Pezdevî, el-Usûl, 1: 224; Molla Fenârî, Füsûlü'l-bedâyî',1: 220, 221; Molla Hüsrev, Mir'âtü'l-usûl, 71, 72.

${ }^{28}$ Pezdevî, el-Usûl, 1: 224; Molla Fenârî, Füsûlü'l-bedâyî',1: 221; Molla Hüsrev, Mir'âtü'l-usûl, 72, 73.

${ }^{29}$ Pezdevî, el-Usûl, 1: 224. Bu konuda, yani sebebiyetin iftitah tekbirini içine alacak son cüz'e kadar tertip üzere intikal etmesinde Hanefî fakîhlerinden İmam Züfer'in (ö. 158/775) farklı bir yaklaşımı bulunmaktadır. Ona göre sebebiyet, tahrimeyi değil edânın sığacağı yani edâyı içine alacak bir cüz'e kadar intikal eder. (Bk. Molla Hüsrev, Mir'âtü'l-usûl, 73).

30 Abdülazîz el-Buhârî, Keșfu'l-esrâr, 1: 215.

31 Pezdevî, el-Usûl, 1: 216.

32 Molla Hüsrev, Mir'âtü'l-usûl, 74.
} 
vaktin edâya yetmemesi sebebiyle namazı edâ edememiştir. Mükellefin edâ kudretine sahip olması ise namazın vücubiyeti için şart değildir. ${ }^{33}$ Şâfiîler ise vaktin son cüz'ünde ehliyetin ortadan kalkmasını itibara almaktadırlar. Dolayısıyla vaktin son cüz'ünde hayız görmeye başlayan kadın, eğer vakit namazını kılmamış ise o namazı kazâ etmekle sorumlu olmaktadır. ${ }^{34}$

Sebebiyet vasfının vaktin belli bir cüz'üne yerleşmesi, ibadete başlama eyleminin (şurû') vaktin herhangi cüz'ünde bulunmasına; vaktin tamamına yerleşmesi ise söz konusu eylemin vaktin hiçbir cüz'ünde bulunmamasına bağlıdır. ${ }^{35}$ Yani vaktin son kısmında da namaz edâ edilmeyip vakit çıkacak olsa, sebebiyet vasfı, artık vaktin yalnızca bir kısmına değil tamamına nispet edilir. Bu durumda vaktin tamamı namazın vücûb sebebi olmuş olur.

$\mathrm{Bu}$ tür vakit birden fazla namazın kılınmasına elverişli olduğu için o vaktin farzına niyet edilmesi ve niyette hangi farzın edâ edileceğinin belirtilmesi (tayin) gerekmektedir. ${ }^{36}$ Dolayısıyla bu tür vakitte namazın, mutlak niyetle edâ edilmesi mümkün olmamakta, vakit dar olsa bile edâ edilecek olan namazın niyette belirtilmesi gerekmektedir. Debûsî bu durumu, vakit içerisinde meșrû olan namazların farklı türlerde olabileceği, Bu nedenle birinin ancak tayin edici bir delil olan niyetle belirginlik kazanabileceği şeklinde ifade etmektedir. ${ }^{37}$

Vaktin bu türüyle ilgili olan hükümlerden biri de müeddânın yani edâ edilecek olan ibadetin ancak edâ etme eylemiyle tayin edilebilmesidir. Yani vaktin herhangi bir kısmının mükellef tarafından sözle sebep olarak belirlenmesi mümkün olmamaktadır. Dolayısıyla öğle namazı vakti içerisinde "Falanca vakitte öğle namazını kılacağım" denilmesiyle o vakit namaz için belirlenmiş olmaz, ancak namazın edâ edilmesiyle vakit tayin edilmiş olur. ${ }^{38}$

\subsection{Mi'yâr, Şart ve (Vücûb İçin) Sebep Olan Vakit}

Debûsî vaktin bu kısmı için "Emredilen fiil için mi'yâr olan vakit" ve "mudayyak" ifadelerini kullanmış ve bu vakti "müvessa' olması tasavvur edilemeyen bir vakit türü" olarak nitelemiştir. ${ }^{39}$ Pezdevî, "Vaktin kendisi için mi'yâr, vücûbu için sebep olduğu ibadetler" ifadesini kullanırken, ${ }^{40}$ Serahsî "Emirle vacip olanın mi'yârı olan vakit" başlığını kullanarak Debûsî’ye yakın bir tutum benimsemiştir. ${ }^{41}$

Sadece emredilen şeyin yapılmasına yeterli olan vakit şeklinde nitelendirilmesi mümkün olan bu tür vaktin "mi'yâr" olarak isimlendirilmesi hususunda Hanefî usul geleneğinde birbirine yakın gerekçelendirmelerin ortaya konduğu görülür. Debûsî’ye göre orucun süresi, oruç tutulan günlerin uzayıp kısalmasına göre uzayıp

\footnotetext{
33 Debûsî, Takvîmu'l-edille, 70.

34 Molla Hüsrev, Mir'âtü'l-usûl, 75.

35 Molla Hüsrev, Mir'âtü'l-usûl, 75, 76.

36 Pezdevî, el-Usûl, 1: 230; Molla Fenârî, Füsûlü'l-bedâŷ̂',1: 223; Molla Hüsrev, Mir'âtü'l-usûl, 83.

37 Debûsî, Takvîmu'l-edille, 70.

38 Molla Hüsrev, Mir'âtü'l-usûl, 83.

${ }^{39}$ Debûsî, Takvîmu'l-edille, 67.

40 Pezdevî, el-Usûl, 1: 230.

41 Serahsî, el-Usûl, 1: 30.
} 
kısaldığı için günler oruç için mi'yâr olmaktadır. Aynı şekilde herhangi bir işi yaptırmak amacıyla günlük işçi kiralanması işleminde de gün, mi'yâr olmaktadır. ${ }^{42}$ Pezdevî, emredilen şeyin söz konusu vakit ile takdir edilmesi ve bilinir olmasını gerekçe olarak zikrederken Serahsî, orucun miktarının ancak vakti ile bilinebileceğini gerekçe olarak zikretmekte ve hacim ölçüsüyle ölçülen malların (keylî) ölçümünde kullanılan mi'yâr benzetmesini yaparak konuya açıklık getirmektedir. ${ }^{43}$

Vaktin bu türü, vakit içerisinde edâ edilecek olan şeyin mi'yârı olmasının yanında vücûbunun da sebebidir. Bu sebebiyet vaktin herhangi bir cüz'üne şahit olmakla gerçekleşmektedir. ${ }^{44}$ Vaktin, ilgili ibadet için hem mi'yâr hem de sebep olmasının örneği Ramazan ayıdır. Ramazan ayı, orucun farz olmasının yani vücûbunun sebebidir. Ayrıca Ramazan ayı oruç için mi'yârdır. Bu vakitte aynı cinsten başka bir ibadeti, yani Ramazan orucu dışında herhangi bir orucu sığdırmak mümkün değildir. ${ }^{45}$ Zira Şâri', mi'yâr olan vaktin yalnızca bir ibadetle meşgul olmasını öngörmüştür. ${ }^{46}$ Mi'yâr olan bu tür vakit içerisinde edâ edilmesi gereken sorumluluğun vaktinden sonraya ertelenmesi (tehir) de caiz değildir. Çünkü vaktin tamamı mi'yâr olduğu için oruç ibadeti ancak vaktin tamamında edâ edilebilmektedir. ${ }^{47}$

Vaktin bu türünde mutlak oruç niyetiyle Ramazan orucunun edâ edilmesi mümkün olmaktadır. Yani bu tür vakitte, edâ edilecek olan sorumluluğun tayin edilmek suretiyle belirgin hale getirilme şartı bulunmamaktadır. ${ }^{48}$ Zira sıfatını belirlemek suretiyle oruca niyet edilmesi, orucu kendisine özel nitelikleriyle tayin etmek ve diğer oruç fiillerinden ayırmak içindir..$^{49}$ Ramazan ayı ise o ayda tutulacak olan oruç için Şâri' tarafından tayin edilmiştir. Ayrıca o ayda başka bir oruç tutulma imkânı bulunmaması yönüyle Ramazan orucunun başka tür oruçlarla karıştırılması gibi bir durum söz konusu olmamaktadır. Örneğin Ramazan ayında oruç tutmak için yapılacak niyette "Ramazan orucu" şeklinde tayin edici bir ifadenin kullanılma zarureti bulunmamaktadır. Hatta Hanefî fakihlerinden Züfer b. Hüzeyl (ö. 158/775), Ramazan ayının Şâri' tarafından oruç için belirlenmiş olması gerekçesine dayanarak niyet edilmeden de oruç tutulabileceği yaklaşımını savunmuştur. Dolayısıyla ona göre orucun rüknü olan imsâk halini bozan herhangi bir şey bulunmadığında niyet edilmeksizin Ramazan orucu tutulabilmektedir. ${ }^{50}$ Fakat Züfer'in bu yaklaşımının, cebir düşüncesini barındırdığı ve ibadetin, bireyin cebir altında olmayan ihtiyarıyla gerçekleştirdiği bir eylem olması gerektiği gibi gerekçelerle Hanefî usul âlimleri tarafından eleştirildiği görülmektedir. ${ }^{51}$

42 Debûsî, Takvîmu'l-edille, 68

43 Pezdevî, el-Usûl, 1: 230; Serahsî, el-Usûl, 1: 36. Benzer izahlar için bk. Molla Fenârî, Füsûlü’l-bedâyî',1: 223.

44 Pezdevî, el-Usûl, 1: 230.

45 Debûsî, Takvîmu'l-edille, 72; Pezdevî, el-Usûl, 1: 230; Molla Hüsrev, Mir'âtü'l-usûl, 87.

46 Pezdevî, el-Usûl, 1: 230; Molla Fenârî, Füsûlü'l-bedâyî',1: 224.

47 Debûsî, Takvîmu'l-edille, 72, 74.

48 Molla Fenârî, Füsûlü'l-bedâyî',1: 224; Molla Hüsrev, Mir'âtü'l-usûl, 87.

49 Debûsî, Takvîmu'l-edille, 73.

50 Debûsî, Takvîmu'l-edille, 73. Pezdevî, el-Usûl, 1: 234; Molla Fenârî, Füsûlü’l-bedâyî‘,1: 224; Molla Hüsrev, Mir'âtü'l-usûl, 89.

${ }^{51}$ Bk. Pezdevî, el-Usûl, 1: 234; Molla Fenârî, Füsûlü'l-bedâyî', 1: 225; Molla Hüsrev, Mir'âtü'l-usûl, 89. 
Ramazan ayında başka bir oruca niyet etmek, dolayısıyla başka bir oruç tutmak meşrû olmadığı için Ramazan ayında kazâ veya nafile oruca niyet edilmiş olsa bile Ramazan orucuna niyet edilmiş kabul edilmektedir. Bu hüküm, mukîm olanlar için söz konusudur. Ramazan ayında başka oruca niyet eden seferî (yolcu) hakkında ise Hanefî mezhebi içinde farklı görüşler ortaya konmuştur. Ebû Yûsuf ve Muhammed eş-Şeybânî̀ye göre Ramazan ayında başka bir oruç meşrû olmadı̆̆ için, seferînin Ramazanda başka bir vâcib orucu edâ etmesi caiz değildir. ${ }^{52}$ Zira seferînin Ramazanda, Ramazan orucu tutması meșrû kılınmış, bununla birlikte yolcu olması sebebiyle kendisine oruç tutmama ruhsatı da tanınmıştır. Ona verilen bu ruhsat, farzdan başka bir orucu meşrû hale getirme işlevine sahip değildir. ${ }^{53}$ Dolayısıyla seferînin, Ramazan orucu dıșında niyet ettiği herhangi bir orucun varlığı söz konusu olmadığı için fiilî olarak gerçekleştirilmesi yani edâ edilmesi mümkün değildir. ${ }^{54}$ Ramazan ayında seferî olan kişiye sadece oruç tutmama ruhsatı verildiğini ifade eden Debûsî̀ye göre ibadette asıl olan vücûbiyetinin düşmemesidir. Nitekim seferî olan kişi Ramazan orucunu tutmak istediği zaman bu asla dayanarak orucu tutabilmektedir. Dolayısıyla Ramazan ayı, vücûbun sebebi ve edânın mahalli olarak devam etmektedir. ${ }^{55} \mathrm{Bu}$ itibarla seferînin başka türden bir oruç tutma imkânı bulunmamaktadır. İmameyn'in benimsemiş olduğu yaklaşıma göre seferînin nafileye niyet etmesi veya niyeti mutlak kullanması durumunda, niyet etmiş olduğu nafile gerçekleşmemekte ve seferî olan mükellef Ramazan orucu tutmuş kabul edilmektedir. ${ }^{56}$

Ebû Hanîfe'ye göre ise Ramazan ayında başka bir vâcibe niyet eden seferînin niyet ettiği vâcib oruç ne ise o tutulmuş kabul edilir. ${ }^{57}$ Zira İslam dini, seferînin Ramazan orucunu edâ etmesi hususunda, ruhsat ve azîmet olarak iki durum getirmiştir. Mükellef Ramazan orucunu tutmamak suretiyle ruhsat yönünü tercih ettiğinde, artık üzerindeki Ramazan orucu yükümlügünü yerine getirme noktasında Ramazan ayı şaban ayı gibi normal bir zaman dilimi olmaktadır. Böyle bir zaman ise diğer türden oruçların tutulması için de uygun olan bir zaman dilimidir. ${ }^{58}$ Ebû Hanîfe'nin ortaya koyduğu bu yaklaşıma göre Ramazan ayında seferînin niyet etmiş olduğu nafilenin de geçerli olması gerektiği sonucu ortaya çıkmaktadır. Bununla birlikte onun iki farklı yaklaşım ortaya koyduğuna dair rivayetler de söz konusudur. İmameyn'in yaklaşımında olduğu gibi Ebû Hanîfe'ye göre de seferînin, Ramazan ayında mutlak niyetle oruç tutması durumunda Ramazan orucu tutulmuş kabul edilmektedir. ${ }^{59}$

Ebû Hanîfe ve İmameyn'e göre hasta olan kişinin Ramazan ayında tutmuş olduğu oruç Ramazan orucu olarak kabul edilmektedir. Zira ona verilen ruhsat, oruç tutma hususundaki acziyeti sebebiyledir. Hastaya öngörülen bu ruhsatın şartı olan acziyet durumu ortadan kalktığında hasta olan kişi sağlıklı insanlarla aynı hükme

\footnotetext{
52 Debûsî, Takvîmu'l-edille, 74; Pezdevî, el-Usûl, 1: 230; Serahsî, el-Usûl, 1: 36; Molla Hüsrev, Mir'âtü'l-usûl, 88.

53 Pezdevî, el-Usûl, 1: 230, 231. Molla Hüsrev, Mir'âtü'l-usûl, 89.

54 Pezdevî, el-Usûl, 1: 231. Abdülazîz el-Buhârî, Keșfu'l-esrâr, 1: 231.

55 Debûsî, Takvîmu'l-edille, 74

56 Pezdevî, el-Usûl, 1: 231;

57 Debûsî, Takvîmu'l-edille, 74; Pezdevî, el-Usûl, 1: 231.

58 Pezdevî, el-Usûl, 1: 231, 232.

59 Pezdevî, el-Usûl, 1: 232.
} 
tabi olmaktadır. ${ }^{60}$

\subsection{Sadece Mi'yâr Olan Vakit}

Debûsî, vaktin bu türü için herhangi bir isimlendirmede bulunmazken Pezdevînnin bu kısım için "Vaktin kendisi için mi'yâr kılındığı fakat sebep kılınmadı̆̆ı ibadetler" başlığını kullandığı ve kendi taksim sisteminde üçüncü kısım olarak incelediği görülmektedir. ${ }^{61}$ Serahsî ise bu türü ikinci kısım kapsamında zikretmektedir. ${ }^{62}$ Tespit edebildiğimiz kadarıyla vaktin bu türünü, müstakil bir bölüm olarak taksime dahil eden ilk usulcü Pezdevî'dir. Sonraki usulcülerden Molla Fenârî de Pezdevî'nin yaklașımını sürdürmüș ve kendi taksim sisteminde beșinci kısım olarak konuya yer vermiștir. ${ }^{63}$ Molla Hüsrev'in de büyük oranda Molla Fenârînnin tutumunu devam ettirdiği görülmektedir. Bununla birlikte o, vaktin bu kısmını "Sadece mi'yâr olan vakit" şeklinde isimlendirmiştir. ${ }^{64}$

Vaktin ibadet için mi'yâr olup, şart ve sebep olmamasının örneği keffâret oruçları, Ramazan orucunun kazâsı ve mutlak olarak nezredilen (nezr-i mutlak) oruçlardır. ${ }^{65}$ Vaktin mi'yâr olması, o vakitte aynı türden ancak bir ibadetin yapılmasının mümkün olması sebebiyledir. Vaktin bu çeşidi, edâ edilecek olan ibadetin edâsının şartı değildir. Yani vakit içerisinde edâ edilecek olan şeyin, bu vakitlerin sonrasına bırakılması halinde kazâya kalma durumu söz konusu olmamaktadır. ${ }^{66}$ Vaktin bu türü, ibadetin edâsının vâcip oluşunun (vücûbu'l-edânın) sebebi de değildir. Zira edânın vâcip olmasının sebebi ilgili naslardır. Ayrıca bu tür vakitler, ibadetin bizzat vâcip olmasının (nefsü'l-vücûbunun) sebebi de değildir. Örneğin nezirde vücûbun sebebi, mükellefin nezretmesidir. Yemin keffâretinin sebebi ise mükellefin yeminini bozmasıdır. ${ }^{67}$

Vaktin bu türü, yukarıda zikredilen oruçlar açısından mi'yâr olmakla birlikte sebep ve şart olmadığı için niyetin ve niyette tayinin bulunması gereklidir. Ayrıca mezkur oruçların ibadet olmaları yönü de niyetin bulunmasını gerekli kılan diğer bir husustur. ${ }^{68}$ Yani bu tür ibadetleri gerçekleștirecek olan mükellef hangi orucu tutacaksa ona niyet etmelidir. Buna göre örneğin Ramazan orucunu kazâ ediyorsa Ramazan orucunun kazâsına, mutlak olarak nezrettiği orucu tutuyorsa nezir orucuna niyet etmelidir. Ramazan ayı ve orucundan farklı olarak vakit, bu türden ibadetler için Şâri' tarafından tayin edilmediği için söz konusu niyetin geceden yapılması gerekmektedir. Zira bu zaman diliminde aynı türden başka ibadetlerin de yapılabilme ihtimali söz konusudur. ${ }^{69}$

Söz konusu vakit, mezkur oruç ibadetleri için tayin edilmediğinden, diğer bir

\footnotetext{
60 Pezdevî, el-Usûl, 1: 232; Molla Hüsrev, Mir'âtü'l-usûl, 88, 89.

61 Pezdevî, el-Usûl, 1: 247.

62 Serahsî, el-Usûl, 1: 42.

63 Molla Fenârî, Füsûlü'l-bedâyî',1: 230.

64 Bk. Molla Hüsrev, Mir'âtü'l-usûl, 93.

65 Pezdevî, el-Usûl, 1: 247; Molla Fenârî, Füsûlü'l-bedâyî',1: 230; Molla Hüsrev, Mir'âtü'l-usûl, 93.

66 Molla Fenârî, Füsûlü'l-bedâyî',1: 230; Molla Hüsrev, Mir'âtü'l-usûl, 94.

67 Molla Hüsrev, Mir'âtü'l-usûl, 94.

68 Pezdevî, el-Usûl, 1: 247; Molla Fenârî, Füsûlü'l-bedâyî',1: 230; Molla Hüsrev, Mir'âtü'l-usûl, 94.

${ }^{69}$ Pezdevî, el-Usûl, 1: 247; Molla Hüsrev, Mir'âtü'l-usûl, 94.
} 
ifadeyle bu tür oruçların Şâri` tarafından tespit edilmek suretiyle belirlenmiş bir vakti bulunmadığından, ibadetlerin yapılmaması suretiyle fevt olması yani kazâya kalma durumu söz konusu değildir. Dolayısıyla keffâret oruçları, Ramazan orucunun kazâsı ve mutlak olarak nezredilen oruçlar ne zaman yapılırsa yapılsın edâ edilmiş olmaktadır. ${ }^{70}$

Vaktin bu kısmıyla ilgili bir diğer hüküm ise vakit içinde edâ edilecek olan ibadetin (müeddâ) vaktinin daralmamasıdır. Yani söz konusu ibadetin hemen yapılması gerekmez. Hanefî mezhebinde yerleşik olan yaklaşım bu şekildedir. Ancak Ebü'l-Hasen el-Kerhî (ö. 340/952) gibi Iraklı Hanefî usulcülere göre, bu tür vakitli ibadetler fevr ifade etmekte yani hemen yapılmayı gerektirmektedir. Kerhî bu görüşü Ebû Yusuf'un (ö. 182/798) görüşü olarak aktarmaktadır. ${ }^{71}$

Abdulazîz el-Buhârî (ö. 730/1330), Pezdevî’nin bu kısmı muvakkat ibadetler içerisinde zikretmesinden hareketle bu kısmı, vakit açısınan mutlak ibadetler içerisinde zikreden âlimlerin olduğunu ifade etmektedir. Zira bu tür vaktin her ikisine de benzerliği bulunmaktadır. Muvakkat ibadetlere benzemesi, ibadetin takdir edilmiş (mukadder) bir zamanla irtibatlı olmasıdır ki, bu zaman gündüzdür. Zekat ibadeti gibi mutlak bir zamanla ilişkilendirilmemiștir. Zira mükellefin, orucu gece tutması dinen muteber değilken zekatı gece edâ etmesi geçerli olmaktadır. Mutlak vakitli ibadetlere benzeyen yönü ise yerine getirilmediği zaman edânın ortadan kalkacağı muayyen bir vakitle ilişkisinin olmamasıdır. ${ }^{72}$ Yani bu türoruçların vakti, muayyen olmayıp bütün ömür olduğu için herhangi bir vakit açısından kaçırılmış olma durumu söz konusu değildir. ${ }^{73}$

\subsection{Mi'yâr, Şart ve (Edânın Vücûbu İçin) Sebep Olan Vakit}

Hanefî usulcülerinden ilk olarak Pezdevî’nin bu vakit çeşidine değindiği görülmektedir. Bununla birlikte Pezdevî, bu vakit türünü bağımsız bir bölüm olarak incelememiş, kendi taksim sisteminde "Vaktin kendisi için mi'yâr, vücûbu için sebep olduğu ibadetler" olarak isimlendirdiği ikinci kısım vakit türü kapsamında ele almıştır. ${ }^{74}$ Abdulazîz el-Buhârî, Pezdevi'nin bu kısmı ikinci kısım kapsamında incelemesini uygun görmez. Ona göre her ne kadar iki vakit türü de mi'yâr olmaları yönüyle ortak bir noktada birleşiyor olsalar da ikinci kısımda yer alan vakit çeşidi, ibadetin vücûb sebebi olurken bu vakit türü ibadetin vücûb sebebi olmamaktadır. Abdulazîz el-Buhârî, bu vakit türünün Pezdevî tarafından "Vaktin kendisi için mi'yâr kılındığı fakat sebep kılınmadığı ibadetler" başlığı altında incelenen üçüncü kısım vakit türü kapsamında ele alınmasının daha uygun olacağı düşüncesindedir. Onun ifadesine göre Pezdevî bu vakit türünün, ikinci kısma benzerliğini daha kuvvetli görmektedir. Zira ikinci kısımda vakit hem mi'yâr hem de edâ şartı olmakta iken, üçüncü kısımda

\footnotetext{
70 Serahsî, el-Usûl, 1: 42; Molla Hüsrev, Mir'âtü'l-usûl, 94.

71 Molla Hüsrev, Mir'âtü'l-usûl, 94.

72 Abdülazîz el-Buhârî, Keșfu'l-esrâr, 1: 247.

73 Apaydın, İslam Hukuk Usulü, 142.

${ }^{74}$ Bk. Pezdevî, el-Usûl, 1: 246;
} 
sadece mi'yâr özelliğine sahip olmaktadır. ${ }^{75}$ Pezdevî tarafından ortaya konan bu yaklaşımın sonraki dönem kimi Hanefî usulcüleri tarafından da sürdürüldügü görülmektedir. ${ }^{76}$ Molla Cîven (ö. 1130/1718) bazı hükümler açısından ortak yönlerin varlığından hareketle her iki bakış açısının mümkün olduğuna vurgu yapmakla birlikte konu ile ilgili tercihini Pezdevî'den yana kullanmaktadır. ${ }^{77}$ Konuya değinen Tetfâzânî (ö. 792/1390), Abdulazîz el-Buhârî tarafından ortaya konan yaklașımı bir adım ileri taşır ve bu kısmın diğer iki kısımla benzerlik yönünü zedeleyen unsurların varlığına dikkat çeker. Ona göre bu tür vakitler, ikinci ve üçüncü kısımdan bağımsız bir vakit türü olarak ele alınmalı ve bu sebeple de muvakkat ibadetlerdeki vakit türleri dört ile sınırlandırılmamalıdır. ${ }^{78}$ Abdulazîz el-Buhârî ve Tetfâzânî tarafından dillendirilen bu görüşün sonraki usulcülerden Molla Fenârî tarafından pratiğe aktarıldığı görülmektedir. Molla Fenârî, taksim iskeletinde dördüncü kısım olarak bu vakit türüne ve ilgili hükümlere yer vermektedir. ${ }^{79}$ Onun bu yaklaşımının, Molla Hüsrev tarafından büyük oranda takip edildiği görülmektedir. ${ }^{80}$

Usulcüler bu vakit türüne; oruç tutmanın veya itikafa girmenin nezredildiği belirli (muayyen) vakti örnek vermektedirler. Bu vakit türü, edâ edilecek olan ibadetin edâsının şartı olmaktadır. Çünkü söz konusu vaktin geçmesiyle ibadetin edâ edilebilme durumu ortadan kalkmaktadır. Ayrıca vakit, söz konusu ibadetin edâsının vâcip olmasının (vücûbu'l-edânın) sebebi olmakla birlikte ibadetin bizzat vâcip olmasının (nefsü'l-vücûbunun) sebebi değildir. Zira ibadetin vâcip olmasının sebebi mükellefin nezretmesidir. ${ }^{81}$

Vaktin bu çeşidi mi'yâr olduğu için, nafile oruca veya mutlak olarak oruç tutmaya niyet edildiğinde nezredilmiş olan vâcip ibadet edâ edilmiş kabul edilir. Bunun yanında niyetin zeval vaktinden önce gerçekleşmiş olması durumunda da nezredilmiş olan ibadetin edâsı mümkün olmaktadır. ${ }^{82}$

Vaktin bu kısmında, nezredilmiş olan vâcipten başka bir vâcib oruç veya itikaf edâ edilebilirken, nafile bir oruca veya itikafa niyet edilmesi durumunda nezredilmiş olan vâcip yerine getirilmiş kabul edilir. Yani bu tür vakitlerde nezredilen vâcipten başka kazâ veya keffâret orucu gibi başka bir vâcip ibadete niyet edilirse, niyet edilen ibadet, söz konusu vakitte gerçekleşir. Nafileye niyet edilmesi durumunda ise nezredilmiş vâcip gerçekleşmiş, nafile gerçekleşmemiş olur. ${ }^{83}$ Söz konusu vakit türü bu yönüyle Ramazan ayından ayrılmaktadır. Zira Ramazan ayında başka bir vâcibe niyet edilmesi durumunda Ramazan orucu gerçekleşmiş olmaktadır. Bunun sebebi Ramazan ayını, o vakitteki oruç ibadeti için tayin eden Şâri' iken bu vakit türünde

\footnotetext{
75 Abdülazîz el-Buhârî, Keșfu'l-esrâr, 1: 247.

${ }^{76}$ Bk. Nesefî, Keșfu'l-esrâr, 1: 91; Molla Cîven, Ahmed b. Ebî Saîd b. Abdillâh el-Leknevî, Nûrü'l-envâr fî șerhi'l-Menâr (İstanbul: İhsan Kitabevi, 1986), 1: 92.

77 Molla Cîven, Nûrül-envâr, 1: 92.

78 Teftâzânî, Sa'düddîn Mes'ûd b. Fahriddîn Ömer b. Burhâniddîn Abdillâh, et-Telvîh ilâ keșfi hakâiki'tTenkîh (Beyrût: Dârü'l-Kütübi'l-İlmiyye, 1981), 1: 408.

79 Molla Fenârî, Füsûlü'l-bedâyî',1: 230.

80 Molla Hüsrev, Mir'âtü'l-usûl, 93.

81 Molla Hüsrev, Mir'âtü'l-usûl, 93.

${ }^{82}$ Nesefî, Keşfu'l-esrâr, 1: 91; Molla Fenârî, Füsûlü'l-bedâyî',1: 230; Molla Hüsrev, Mir'âtü'l-usûl, 93.

83 Pezdevî, el-Usûl, 1: 246; Molla Hüsrev, Mir'âtü'l-usûl, 93.
} 
nezirde bulunan mükellefin kendisi olmasıdır. Mükellefin yapmış olduğu bu tayin işlemi kendi hakkında etkili olurken vakti Şâri' tarafından tayin edilen başka bir vâcibe etki etmemektedir. ${ }^{84}$

\subsection{Zarf, Şart ve (Edânın Vücûbu İçin) Sebep Olan Vakit}

Tespit edebildiğimiz kadarıyla Hanefî usul geleneğinde vaktin bu türü ve ilgili hükümlerinden bahseden ilk usul âlimi Molla Fenârî'dir. Molla Fenârî, bu vakit türüne kendi taksim sisteminde üçüncü kısım olarak ve müstakil bir başlık altında yer vermiştir. ${ }^{85} \mathrm{Bu}$ durumun, onun fıkıh usulü alanında yetkinliğini göstermesinin yanında Hanefî usul düşüncesine yapmış olduğu katkıların varlığına dikkat çekmesi yönüyle önem arz ettiği söylenebilir. Sonraki usulcülerden Molla Hüsrev'in de konu ile ilgili olarak Molla Fenârî'nin yaklaşımını benimsediği görülmektedir. ${ }^{86}$

Molla Fenârî bu vakit türüne, namaz kılınması veya sadaka verilmesi nezredilmiş olan belirli (muayyen) vakit örneğini verir. Bu vakit türü, söz konusu ibadet edâ edildikten sonra arttığı için edâ dilecek olan ibadetin zarfı olmaktadır. Vaktin çıkmasıyla edâ edilebilme durumunun ortadan kalkması anlamında nezredilmiş olan ibadetin edâsının şartı ve söz konusu ibadetin edâsının vâcip olmasının (vücûbu'l-edânın) sebebidir. Bu tür vakitte ibadetin bizzat vâcip olmasının (nefsü'l-vücûbun) sebebi mükellefin nezretmesidir. ${ }^{87}$

Bu kısım vaktin hükmü; edânın, söz konusu vakit üzerine takdim edilmesinin câiz olmasıdır. Dolayısıyla edâ, muayyen olan vakitten önce gerçekleşebilir. Çünkü nefsü'l-vücûb, nezretme ile zaten gerçekleşmiştir. ${ }^{88}$

\subsection{Müșkil vakit}

Bu vakit türünü Debûsî "Müşkil olan belirli vakit", 89 Serahsî "Müșkil, müștebih vakit"90 Pezdevî "Müşkil olan muvakkat ibadet", 91 Molla Fenârî ise "Vakti müşkil olan edâ" olarak isimlendirmiştir. ${ }^{92}$ Sonra gelen Hanefî usulcülerinin, vaktin bu türü için genel olarak "müşkil vakit" ifadesini kullandıkları görülmektedir. ${ }^{93}$ Serahsî̀nin "müşkil" kavramından sonra "müştebih" ifadesine yer vermesinin, incelediğimiz

\footnotetext{
${ }^{84}$ Pezdevî, el-Usûl, 1: 246; Nesefî, Keșfu'l-esrâr, 1: 91; Molla Hüsrev, Mir'âtü'l-usûl, 93.

85 Molla Fenârî, Füsûlü'l-bedâyî',1: 228.

86 Bk. Molla Hüsrev, Mir'âtü'l-usûl, 92.

87 Molla Fenârî, Füsûlü'l-bedâyî',1: 228; Molla Hüsrev, Mir'âtü'l-usûl, 92.

${ }^{88}$ Molla Fenârî, Füsûlü'l-bedâŷ̂‘',1: 228, 229. Buna benzer bir durum zekat ibadetinde de söz konusudur. Zira zekatta nisâb, nefsü'l-vücûbun sebebidir. Bu itibarla senenin başında nisâb miktarı mala sahip olan mükellefin bir kameri yılın geçmesini beklemeden zekatını vermesi caiz olmaktadır. Çünkü zekatın nefsü'l-vücûbu olan nisâb miktarı mal mevcuttur. Bk. Molla Hüsrev, Mir'âtü'l-usûl, 92.

89 Debûsî, Takvîmu'l-edille, 67.

90 Serahsî, el-Usûl, 1: 30.

91 Pezdevî, el-Usûl, 1: 248.

92 Molla Fenârî, Füsûlü'l-bedâyî', 1: 230.

93 Bk. Nesefî, Keșfu'l-esrâr, 1: 93; Molla Cîven, Nûrü'l-envâr, 1: 92; Molla Hüsrev, Mir'âtü'l-usûl, 94. Bunun yanında "meşkûkun fih vakit", "müşkil zamanlı vâcip" ve "zü’ş-şebeheyn vâcip" gibi ifadelerinin de kullanıldığı görülür. Konu ile ilgili olarak bk. Hanbelîzâde, Usûlü'l-fıkhi'l-İslâmî, 74; Dönmez, İbrahim Kâfi, "Vâcip", Türkiye Diyanet Vakfı İslâm Ansiklopedisi (İstanbul: TDV Yayınları, 2012), 42: 412.
} 
kavram ile lafızlar (elfâz) taksiminde yer alan "müşkil" terimi arasında gerçekleşebilecek muhtemel karışıklığı gidermeye yönelik olduğu ifade edilebilir. Nitekim usul geleneğinde bu mahzuru dillendiren usulcüler de bulunmaktadır. ${ }^{94}$

Vaktin bu kısmının örneği hac ibadetinin yapıldığı vakittir. Vaktin bu çeşidinin "müşkil" olarak nitelendirilmesi hususunda Hanefî usul âlimleri arasında birbirine yakın gerekçelendirmelerin zikredildiği görülür. Debûsî’nin ifadesine göre hac ibadetinin yapıldı̆̆ı aylar Şevvâl ve Zilkade aylarının tamamı ile Zilhicce ayının on gününü kapsamaktadır. Bu vakit, bir sene içerisinde birden fazla hac yapılması mümkün olmaması yönüyle mudayyak vakte, hac ibadetinin bütün vakti kapsamaması yönüyle de müvessa' vakte benzemektedir. Bundan dolayı bu vakit "müșkil" olarak isimlendirilmiștir. ${ }^{95}$ Benzer ifadelere yer veren Pezdevî ve Serahsî̀ye göre ise müşkil olma durumu iki açıdan söz konusu olmaktadır. Birincisi; hac ibadeti belirli fiillerle edâ edilebilen bir ibadettir ve bu fiillerin edâsı vaktin tamamını kapsamamaktadır. Bu yönüyle hac ibadeti namaza benzemektedir. Bir sene içinde ancak bir hac ibadeti yapılabilmesi yönüyle de oruca benzemektedir. İkinci olarak; hac ibadetinin vakti bütün ömürdür. Dolayısıyla her bir yılın hac ayları, hac ibadetinin edâsına uygun bir zaman dilimi olmaktadır. Bu yönüyle de zarfa benzemektedir. Haccın mükellefe farz olduğu ilk senenin ayları ise hac ibadeti için muayyen bir vakit olmaktadır. Bununla birlikte ilk senede başka bir hac ibadetinin yapılması mümkün değildir. Bu yönüyle de mi'yâra benzerliği bulunmaktadır. ${ }^{96}$ Molla Fenârî ve Molla Hüsrev'in konuyla ilgili olarak benzer ifadelere yer verdikleri görülmektedir. ${ }^{97}$

Hanefî mezhebinde bu kısmın hükmüyle ilgili olarak farklı görüşler ortaya konulmuştur. Hanefî fakihleri hac ibadetinin, mükellefe farz olmasından sonra hangi yıl edâ edilirse edilsin sahih ve geçerli olduğu noktasında görüş birliğinde olmalarına karşılık,98 ibadetin ilk sene edâ edilmeyip sonraki bir yıla ertelenmesinin câiz olup olmadığı noktasında ayrılığa düșmüşlerdir. ${ }^{99}$ Ebû Yûsuf, bu tür vakitlerin mi'yâr yani mudayyak olma yönünü tercih etmiş ve mazeretsiz bir şekilde gelecek seneye tehir edilmesinin câiz olmadığını, dolayısıyla tehir edilmesi durumunda mükellefin günahkâr olacağını ifade etmiştir. ${ }^{100}$ Ebû Yûsuf'a göre haccın mükellefe farz olduğu sene hac vaktinin geçmesiyle (fevt) ibadetin o sene edâ edilebilme durumu ortadan kalkmaktadır. Kişinin bir sonraki seneye ulaşması ise şüphelidir. Dolayısıyla mükellefin sonraki seneye ulaşmasını gerçekleşmiş bir durum olarak değerlendirip ertelemesine câiz hükmünün verilmesi doğru değildir. Bununla birlikte mükellefin kendisine farz olan hac ibadetini edâ etmemesi ve bu suretle hac vaktinin geçirilmesi ise sabit bir durum olup hükmün bu mevcut durum göz önüne alınarak verilmesi daha uygun olmaktadır. Dolayısıyla mükellefin kendisine farz olduğu sene

\footnotetext{
94 Bk. Ebü'l-Hasenât Muhammed Abdülhay b. Muhammed Abdilhalîm b. Muhammed Emînillâh esSihâlevî el-Leknevî (1848-1886), Kamerü'l-akmâr (İstanbul: İhsan Kitabevi, 1986), 2: 93.

95 Debûsî, Takvîmu'l-edille, 67.

96 Pezdevî, el-Usûl, 1: 248; Serahsî, el-Usûl, 1: 42.

97 Bk. Molla Fenârî, Füsûlü'l-bedâyî', 1: 230; Molla Hüsrev, Mir'âtü'l-usûl, 94.

98 Debûsî, Takvîmu'l-edille, 71.

${ }_{99}$ Molla Hüsrev, Mir'âtü'l-usûl, 94.

100 Molla Fenârî, Füsûlü'l-bedâyî', 1: 230; Molla Hüsrev, Mir'âtü'l-usûl, 95.
} 
hac ibadetini bilerek yapmaması (tefvît) haramdır. ${ }^{101}$

Muhammed eş-Şeybânî ise bu tür vakitlerin mevessa' yani zarf olma yönünü tercih etmiştir. Ona göre hac ömürlük bir ibadettir. Dolayısıyla ilk seneden sonraya tehir edilmesi câiz olmaktadır. ${ }^{102}$ Bununla birlikte İmam Muhammed'in öngörmüş olduğu bu cevâz hükmünün kapsamında bir daraltmaya yer verdiği görülür. Ona göre öleceğine dair herhangi bir kanaate (zann-ı gâlibe) sahip olmayan mükellefin bu tür ibadetleri ertelemesinde herhangi bir sakınca bulunmamaktadır. ${ }^{103}$

Hac ibadeti, ömür içinde edâ edilebilir olduğu için kendisine hac farz olan kişinin, nâfile hacca niyet etmesi durumunda nâfile haccı sahih olur. ${ }^{104}$ Zira hac ibadeti, başka bir hac ibadetinin gerçekleştirilmesine engel teşkil etmez. Bununla birlikte Ebû Yûsuf'un da belirttiği gibi hac ibadeti dar zamanlı (mudayyak) olarak vacip olduğu için bir senede ancak bir hac ibadeti yapllabilir. 105

Mükellef, hac ibadeti kendisine farz olduktan sonra ilk sene edâ etme imkânı var iken edâyı ertelese ve bu hal üzere vefat etse sorumluluk zimmetinden düşmüş olmaz. Zira ilk sene edâ imkânı var iken yapmayıp haccı ertelemesi durumunda tevfît (bilerek yapmama) durumu söz konusu olmaktadır. Nitekim keffâretlerde de böyle bir durum söz konusudur. Mükellef, keffâret yükümlülügünü yerine getirme imkânı varken yapmaz ise keffâret zimmetinden düşmüş olmaz. ${ }^{106}$

\section{Sonuç}

Dinî alanda mükelleflerden yapılması istenen sorumlulukların vakitle sıkı bir irtibatı söz konusudur. Bu itibarla erken dönemden itibaren fıkıh usulü âlimleri, Şârî'in emrinin veya Şârî' tarafından emredilen șeyin (me'mûr bih) vakitle irtibat yönünü incelemişler ve kendi usul düşüncelerini ortaya koyarak konuya katkı sağlamışlardır.

Herhangi bir vakitle kayıtlı olup olmaması yönüyle emir, mutlak ve mukayyed olarak iki kısma ayrılmaktadır. Bu taksime göre mutlak emir; yapılması istenilen işin, bir vakitle kayıtlanmadığı emirdir. Mukayyed emir ise yapılması istenen şeyin belirli (muayyen) bir vakit içinde yapılmasını öngören emirdir. Vakitle kayıtlanmış olan emirle, mükelleften yapılması istenen şeyin, emrin öngörmüş olduğu vakit içerisinde yapılması gerekmektedir. Dolayısıyla vakitten sonra yapılması durumunda kazâ veya gayr-i meşrû olma gibi hususlar söz konusu olmaktadır.

Hanefî usul âlimleri, emri veya me'mûr bihi, zamanla kayıtlı olması açısından muhtelif kısımlara ayırmışlardır. "Müvessa' vakit", "mi'yâr vakit" ve "müşkil vakit" şeklinde yaygın bir sınıflandırma söz konusu olmakla birlikte dörtlü ve altılı taksimler de bulunmaktadır. Hanefî usul alimlerinden Pezdevî, söz konusu yaygın taksime bir kısım ilave etmiş ve bu yönüyle vakitleri dört kısımda ele almıştır. Sonraki dönem Hanefî usulcülerinden Molla Fenârî ise vakitleri altı kısma taksim etmiştir.

101 Debûsî, Takvîmu'l-edille, 70.

102 Debûsî, Takvîmu'l-edille, 70; Pezdevî, el-Usûl, 1: 249; Molla Fenârî, Füsûlü'l-bedâyî', 1: 230; Molla Hüsrev, Mir'âtü'l-usûl, 96.

103 Molla Fenârî, Füsûlü'l-bedâyî', 1: 230, 231; Molla Hüsrev, Mir'âtü'l-usûl, 96.

104 Molla Hüsrev, Mir'âtü'l-usûl, 97.

105 Debûsî, Takvîmu'l-edille, 71.

106 Debûsî, Takvîmu'l-edille, 72. 
Molla Fenârî tarafından ortaya konan bu taksimin, Molla Hüsrev tarafından da büyük ölçüde benimsendiği görülmektedir. Hanefî usul geleneğinde, emrin veya emredilen şeyin bir kaydı olması yönüyle vakit çeşitlerinin şu şekilde ifade edilmesi mümkündür:

1. Zarf, Şart ve (Vücûb İçin) Sebep Olan Vakit

2. Mi'yâr, Şart ve (Vücûb İçin) Sebep Olan Vakit

3. Sadece Mi'yâr Olan Vakit

4. Mi'yâr, Şart ve (Edânın Vücûbu İçin) Sebep Olan Vakit

5. Zarf, Şart ve (Edânın Vücûbu İçin) Sebep Olan Vakit

6. Müşkil vakit

$\mathrm{Bu}$ vakit türlerinden birinci, ikinci ve altıncı kısımda yer alan vakitler yaygın olarak bilinen vakit türleridir. Üçüncü kısımda yer alan vakit çeşidini ise müstakil bir bölüm olarak taksime dahil eden ilk usulcü Pezdevî'dir. Sonraki usulcülerden Molla Fenârî de Pezdevî̀nin yaklaşımını sürdürmüş ve kendi taksim sisteminde beşinci kısım olarak konuya yer vermiştir. Dördüncü kısımda yer alan vakit türüne Hanefî usulcülerinden ilk olarak Pezdevî’nin değindiği görülmektedir. Bununla birlikte Pezdevî, bu vakit türünü bağımsız bir bölüm olarak incelememiş, ikinci kısımda yer alan vakit türü kapsamında ele almıștır. Vaktin bu kısmını ve hükümlerini müstakil olarak taksime dahil eden ilk usulcü Molla Fenârî'dir. Molla Fenârî bu vakit türüne, kendi taksim iskeletinde dördüncü kısım olarak yer vermiştir. Hanefî usul geleneği incelendiğinde beşinci kısımda yer alan vakit türüne ve ilgili hükümlerine yer veren ilk usulcünün Molla Fenârî olduğu görülmektedir. Molla Fenârî bu vakit türüne kendi taksim sisteminde üçüncü kısım olarak ve müstakil bir başlık altında yer vermiştir. Molla Fenârî̀nin bu yaklaşımının, sonraki usulcülerden Molla Hüsrev tarafından da benimsendiği görülmektedir.

Konu özelinde Pezdevî ile başlayan ve sonraki dönem usul âlimlerinden Molla Fenârî tarafından da sürdürülen farklı görüş ve eleştirilerin teoriye yansıtıldığı söylenebilir. Her iki usulcünün özellikle de Molla Fenârînnin, Hanefî usul düşüncesinde emrin veya emredilen şeyin (me’mûr bih) vakitle ilişki yönünün teorik düzeyde gelişmesine önemli katkıları olmuştur. Ayrıca bu araştırma neticesinde elde edilen veriler ıșığında Hanefî mezhebinin usul düşüncesinin dinamik bir yapıya sahip olduğu da ifade edilebilir.

\section{Kaynakça}

Abdülazîz el-Buhârî, Alâüddîn b. Ahmed b. Muhammed. Keş̧fu'l-esrâr an Usûl-i Fahri'l-İslâm el-Pezdevî. 2 Cilt. İstanbul: Şirket-i Sahâfe-i Osmâniye, 1308/1890.

Apaydın, Yunus. İslam Hukuk Usulü. 2. Baskı. Kayseri: Kimlik Yayınları, 2016.

Cessâs, Ebû Bekir Ahmed b. Ali er-Râzî. el-Füsûl fi'l-usûl. Thk. Uceyl Câsim en-Neşemî. 2. Baskı. 4 Cilt. Kuveyt: Vizâretü'l-evkâf ve'ş-şuûni'l-İslâmiyye, 1994.

Debûsî, Ebû Zeyd Abdullahb. Muhammed b. Ömer b. Îsâ. Takvîmu'l-edille fi usûli'l-fikh. Thk. Halil Muhyiddin Meys. Beyrût: Dârü'l-kütübi'l-ilmiyye, 1421/2001.

Dönmez, İbrahim Kâfi, "Vâcip", Türkiye Diyanet Vakfi Íslam Ansiklopedisi. 42: 410-414. İstanbul: TDV Yayınları, 2012.

Ebü'l-Hasenât Muhammed Abdülhay b. Muhammed Abdilhalîm b. Muhammed Emînillâh es-Sihâlevî elLeknevî. Kamerü'l-akmâr. İstanbul: İhsan Kitabevi, 1986.

Hanbelîzâde, Muhammed Şâkir. Usûlü'l-fıkhi'l-İslâmî. 1. Baskı. Beyrût: Dârü'l-Beșâir, 2004.

Molla Cîven, Ahmed b. Ebî Saîd b. Abdillâh el-Leknevî. Nûrü'l-envâr fî şerhi'l-Menâr. İstanbul: İhsan 
Kitabevi, 1986.

Molla Fenârî, Şemseddîn Muhammed b. Hamza b. Muhammed. Füsûlü'l-bedâyî́ fî usûli'ş-şerâi'. Thk. Muhammed Hasen Muhammed Hasen İsmail. 1. Baskı. 2 Cilt. Beyrût: Dârü'l-Kütübi'l-İlmiyye, 2006.

Molla Hüsrev, Mehmed. Mir'âtü'l-usûl. İstanbul: Salah Bilici Kitapevi, ty.

Pezdevî, Ebü’l-Hasen Ebü'l-Usr Fahrü'l-İslâm Alî b. Muhammed b. el-Hüseyn b. Abdilkerîm. el-Usûl. 2 Cilt. İstanbul: Şirket-i Sahâfe-i Osmâniye, 1308/1890.

Nesefî, Ebü'l-Berekât Hâfızüddîn Abdullah b. Ahmed b. Mahmûd. Menârü'l-envâr. 2 Cilt. Dimaşk: Dârü'lFarfûr, 2001.

Nesefî, Ebü'l-Berekât Hâfızüddîn Abdullah b. Ahmed b. Mahmûd. Keșfu'l-esrâr şerhu'l-musannif ale'lMenâr. İstanbul: İhsan Kitabevi, 1986.

Serahsî, Ebû Bekir Muhammed b. Ahmed b. Ebî Sehl. el-Usûl. Thk. Ebû'l-Vefâ el-Afğânî. 2 Cilt. Beyrût: Dâru'l-Fikr, 2005.

Seydișehrî, Mahmud Esad. Teshîl-u Usûl-i Fıkıh. 1. Baskı. İstanbul: Yasin Yayınları, 2002.

Seyyid Bey. Usûl-i Fıkıh Dersleri. İstanbul: y.y., 1913.

Teftâzânî, Sa'düddîn Mes'ûd b. Fahriddîn Ömer b. Burhâniddîn Abdillâh. et-Telvîh ilâ keșfi hakâiki'tTenkîh. 2 Cilt. Beyrût: Dârü'l-Kütübi'l-İlmiyye,1981.

Yahyâ Maabdeh. "el-Ehâdîsü'l-vâride fî tahdîdi bedi' duhûli vakti'l-mağrib dirâseten nakdiyyeten fî dav'i ilmi'l-felek". İslam Hukuku Araştırmaları Dergisi 31 (Nisan 2018): 469-489.

\section{Summary}

Time is one of the important concepts in human life. Time is a process that can only be consciously perceived by human beings, although it is associated with all beings. Because the only entity that can think about time is human. Islam has not neglected the direction of human contact with time, has given special importance to the importance of time and should not be neglected, and has given various orders and recommendations. In Islam, the issue of regulating human life in accordance with Allah's commands and prohibitions is an important matter. In this context, worships in Islam; the daily, weekly and annual prayers are arranged in a timely form.

With these features, it can be said that acts of worship are also helpful in keeping the consciousness of the servants alive.

When the works of Islamic law are examined, it can be seen that, with the features of acts of worship and related subjects, those related to time are included. On the other hand, there is a theoretical aspect of the subject. Acting from this standpoint, the scholars of the usul al-fiqh have examined the direction of the relationship of what was ordered by Shari's speech with time and contributed to the issue by making a different division. The order is divided into two parts as "mutlak" and "mukayyad" in terms of whether a subject is limited to any time. According to this division of mutlak order; it is an order in which the requested thing to do (ma'mûr bih) is not limited to any time. The Mukayyad order is not like this. In the mukayyad order, the thing that is required from those responsible (mukallaf) should be done within a certain time.

The Hanafi scholars of usul al-fiqh divided the order or what was ordered into various parts in terms of whether or not it was limited in time. It is generally known that there is a widespread classification in usul al-fiqh as "wide time", "narrow time" and "equivocal time". There are also scholars who divided the time into four and six parts.

Al-Bazdawî (d. 482/1089), one of the Hanafí scholars of usul, added a part to this widespread division and in this respect, he examined time in four parts. Mollâ Fanârî (d. 834/1431), one of the Hanafî scholars of usul who lived in the following period, divided time into six parts. It's seen that this division, made by Mollâ Fanârî, was also largely adopted by Mollâ Khusraw (d. 885/1480).

As stated before, the time types which are expressed as "wide time", "narrow time" and "equivocal time" are commonly known in usul al-fiqh. The example of wide time is the time of prayer (salât). The example of narrow time is the month of Ramadan which is the time of fasting and the example of the equivocal time is the time of hajj. Apart from these, it is seen that some Hanafi scholars of usul al-figh added new types of time to the classification. al-Bazdawî, one of the Hanafí scholars of usul, included a variety of time in the name "only a narrow time". This type of time is not the cause and condition of worship. The meaning of time being "narrow" is that it is possible to make only one worship of the same kind at that time. Since this type of time is not a cause and a condition, it should be intended when worshiping. Mollâ Fanârî also continued al-Bazdawî's approach to the subject and included this kind of time as the fifth part in his division system.

Again, al-Bazdawî is the first scholar who refered to another kind of time. Although this type of time is narrow, it is the condition of worship and the reason for the practice of worship. al-Bazdawî has not 
(Vakit Teorisinin Gelişimi Üzerine Bir İnceleme)

examined this type of time as an independent section, but has studied it under the heading of "narrow time" that has taken in the second section. The first scholar of usul al-fiqh who included this kind of time and related provisions as an independent section in the division is Mollâ Fanârî. Molla Fenârî has included this kind of time as the fourth part in his division system. There is another type of time in the time division. Although this type of time is wide, it is the condition of worship and the reason for the practice of worship. When the tradition of usul al-fiqh of Hanafi is examined, it is seen that Mollâ Fanârî was the first scholar of usul who included this type of time and related provisions. Mollâ Fanârî examined this kind of time independently and in the third part of his division system. It is seen that Mollâ Fenârî's approach regarding this type of time was adopted by Mollâ Khusraw.

Regarding the development of time theory in the usul al-fiqh of Hanafi, the following points can be briefly mentioned. In the tradition of usul al-fiqh of Hanafi, the connection of time with the order or what was ordered (ma'mûr bih) is examined in detail and systematically. Since the early periods, the problems around the subject have been examined and answers have been sought. The scholars of the usul al-figh of Hanafi have put forward ideas reflecting their own approaches in relation to the time theory. In this context, it is necessary to emphasize the importance and role of al-Bazdawî who is one of the scholars of usul. Because he was the first person to draw attention to the logical inconsistency in the widely known time division. This difference of opinion, which began with al-Bazdawi, was continued by Molla Fanârî, one of the scholars of usul who lived in the following period. al-Fanârî took the subject one step further and mentioned the existence of different kinds of time. This is important in terms of demonstrating the existence of his deep knowledge in the field of usul al-fiqh. In this sense, it can be said that al-Bazdawî and Mollâ Fanârî had important effects and contributions on the theoretical development of the subject. In addition, it is necessary to emphasize Mollâ Khusraw's contribution on the subject. Mollâ Khusraw has continued al-Fanârî's approach to the time theory and has made important contributions to the updating of the subject. Especially in naming of parts of time, it can be seen that the final form was given by Molla Khusraw. According to the data obtained from the research, it is understood that the theory of time has a content which has a development in the tradition of usul al-fiqh of Hanafi. On the other hand, when the discussions around the subject are looked at, it is also seen that the thought of usul al-figh of Hanafi has a dynamic structure. 